POLITYKA ENERGETYCZNA - ENERGY POLICY JOURNAL

$2021 \downarrow$ Volume $24 \uparrow$ Issue $1 \uparrow 153-168$

DOI: $10.33223 / \mathrm{epj} / 130209$

Krystian MajchrzaK ${ }^{1},{\text { Piotr } \text { OlczaK }^{2} \text {, Dominika MatuszewsKa }}^{3}$, Magdalena Wdowin ${ }^{4}$

\title{
Economic and environmental assessment of the use of electric cars in Poland
}

ABSTRACT: Electromobility and electric cars are the words that began to gain significance in the social discourse in Poland especially intensively since 2017. Then, along with the announcement of the „Plan for the Development of the Electromobility Market in Poland”, government declarations appeared regarding one million electric cars that are to be used on Polish roads by 2025. It is already known today that such a result in Poland is impossible to achieve in the assumed time. According to the report of the Polish Alternative Fuels Association-PSPA (Polish EV Outlook 2020), in the event of introducing subsidies for the purchase of cars or subsidies, such as the possibility of $100 \%$ VAT deduction by buyers of such vehicles, the number of electric cars in Poland in 2025 could be over 280 thousand pcs. Without such government support, the Polish electric car park will be twice smaller. High prices of electric cars are one of the key barriers limiting Poles in making decisions related to the purchase of a vehicle. The aim of this article is to analyse the current state of the social environment in relation to the topic of ecological, electric cars. To what extent is it beneficial for

$\triangle$ Corresponding Author: Krystian Majchrzak; e-mail: krystian.majchrzak@instaway.pl

${ }^{1}$ Foundation Instaway Institute, Warszawa, Poland; e-mail: krystian.majchrzak@instaway.pl

2 Mineral and Energy Economy Research Institute of the Polish Academy of Sciences, Kraków, Poland; ORCID iD: 0000-0002-4926-0845; e-mail: olczak@min-pan.krakow.pl

3 AGH University of Science and Technology, Kraków, Poland; ORCID iD: 0000-0002-8899-012X; e-mail: dommat@agh.edu.pl

4 Mineral and Energy Economy Research Institute of the Polish Academy of Sciences, Kraków, Poland; ORCID iD: 0000-0002-5097-719X; e-mail: wdowin@min-pan.krakow.pl

2021. The Author(s). This is an open-access article distributed under the terms of the Creative Commons Attribution-ShareAlike International License (CC BY-SA 4.0, http://creativecommons.org/licenses/by-sa/4.0/), which permits use, distribution, and reproduction in any medium, provided that the Article is properly cited. 
the potential car owner to change from a traditional (petrol or diesel) car to an electric car due to purely financial benefits and other aspects? The article consists of an overview - presenting aspects related to the socio-economic benefits of buying an electric car. It also contains specific calculations regarding the profitability of using such a car in Polish conditions.

KEYwORDs: ecology, transport, electric vehicles, electromobility, NPV

\section{Introduction}

Speaking of electromobility or e-mobility, the authors adopted the interpretation of this concept after Karoline Augeinstein (2009), who describes mobility 3.0 as a "multidimensional concept, taking into account technological and organizational elements, relating to legal and economic issues as well as touching the sphere of attitudes and behaviors". In the opinion of the authors of the publication of the European Financial Congress, "e-mobility is of key importance in the ongoing public discussion on the future development of socio-economic systems - both on a global, European and Poland scale" (Gajewski et al. 2017). The paper presents an analysis aimed at evaluating the profitability of using electric cars in Poland. During the analysis, the net present value (NPV) profitability ratio was calculated depending on the electricity price for charging, the price of the replaced fuel and the annual distance covered by drivers. The NPV was calculated at both a zero and $6 \%$ discount rate. Moreover, the impact of replacing traditional cars with electric ones on the reduction of $\mathrm{CO}_{2}$ emissions was calculated. These calculations concern several indicators of electricity and fuel consumption for every $100 \mathrm{~km}$ distance, as well as specific $\mathrm{CO}_{2}$ emissions of electricity and fuel.

\section{Changes in transport as a response to environmental challenges}

As a result of climate change caused by human activity, problems related to global warming are transferred to the plane of everyday experience from the sphere of scientific considerations. According to the climate goals set by the European Commission in 2011, by 2050 there should be about a billion electric vehicles and almost complete elimination of combustion vehicles from cities. Thanks to the changes in transport, it will be possible to reduce $60 \%$ of the total carbon dioxide emissions (European-Comission 2011). Changes are inevitable because, according to the reports of the World Health Organization, approx. 91\% of the world's population lives in areas where poor air quality affects their health and life (World Health Organization 2020). Such 
a situation is an important starting point for all activities, from legislative and formal solutions, to social campaigns raising awareness of the need for changes. In the case of economic analyses, purely financial factors are taken into account in the first place, although issues of a worldview nature, which reflect changing trends and consumer behavior, are also not without significance (Brdulak et al. 2020; Drożdż et al. 2020). The data contained in the "Polish EV Outlook 2020" report of the Polish Alternative Fuels Association (PSPA) of April 29, 2020 was adopted as the source for the development of profitability estimates for the implementation (PSPA 2020b). The report contains scenarios for the development of the electromobility sector in Poland, in variants assuming the implementation of financial or tax incentives, as well as in the absence of government support. In a realistic scenario, assuming the introduction of subsidies or appropriate tax incentives, e.g. allowing a 100\% VAT deduction, the number electric cars in Poland in 2025 may exceed 280,000 pcs. The report also estimates that the number of PHEV cars (plug-in hybrid electric vehicle) in 2025 will be approx. 160,000 pcs. Both numbers will add up to 440,000 electric cars on Polish roads. Estimates for 2030 assume 570,000 BEV cars and the number of PHEV cars will approach 900,000 pcs., which indicates the size of the zero- and low-emission car park (BEV and PHEV) in Poland in 10 years at 1.5 million pcs (Jurasz and Ciapała 2019). These estimates, together with a less optimistic scenario - without subsidies from the government - are presented in Table 1. In the last 5 years, the annual sales of battery electric vehicles (BEV) and plug-in hybrid electric vehicles (PHEV) in Poland increased by 1,268\% - from 316 in 2015 to 4,322 in 2019. At the end of last year, the fleet of electric cars registered in Poland was 10,232 pcs. (+ $73 \%$ year/year), of which $49 \%$ were BEV and $51 \%$ PHEV.

TABLE 1. The number of electric cars in Poland - estimations

TABela 1. Liczba samochodów elektrycznych w Polsce - oszacowanie

\begin{tabular}{|c|c|c|}
\hline \multicolumn{2}{|c|}{$\begin{array}{c}\text { Reference scenario from the } \\
\text { "Polish EV Outlook 2020" report }\end{array}$} & $\begin{array}{c}\text { Pessimistic scenario from the } \\
\text { "Polish EV Outlook 2020" report }\end{array}$ \\
\hline \multicolumn{3}{|c|}{ BEV } \\
\hline 2025 & 280,000 pcs. & 130,000 pcs. \\
\hline 2030 & 884,000 pcs. & 552,000 pcs. \\
\hline \multicolumn{3}{|c|}{ PHEV } \\
\hline 2025 & 160,000 pcs. & 160,000 pcs. \\
\hline 2030 & 570,000 pcs. & 570,000 pcs. \\
\hline \multicolumn{3}{|c|}{ (BEV and PHEV) } \\
\hline 2025 & 440,000 pcs. & 290,000 pcs. \\
\hline 2030 & $\sim 1.5$ million & $\sim 1.1$ million \\
\hline
\end{tabular}

Source: own study based on the PSPA Report (PSPA 2020b).

The growth of the market is also influenced by the growth rate of the number of electric vehicles charging stations. The "Polish EV Outlook 2020" report assumes that the number of 
charging points installed in public stations will increase from the current 2,100 up to 40,000 in 2025 and 91,000 in 2030 (PSPA 2020b).

According to the "Electromobility Barometer" (BZ-WBK 2018), prepared on the basis of a survey of the mood of Polish society conducted in $2018,17 \%$ of the interviewed people considered purchasing an electric vehicle over the next three years, which was a five percent increase compared to 2017. Poles declared that they were able to spend PLN 80,000 to 90,000 on the purchase of an electric car. These amounts are still below the list price of electric cars (the list price of the new Nissan Leaf is around EUR 30,000). It is also worth mentioning that factors such as exemption from VAT or the possibility of receiving a subsidy for the purchase of such a car were indicated as factors favoring decisions to purchase an electric vehicle. Benefits such as the possibility of using bus lanes or free parking were also important. They are also aspects contributing to saving time and money. One of the barriers discouraging potential users of electric cars from purchasing such a vehicle is the lack of a well-prepared network of charging infrastructure (this is connected with relatively low battery capacities (Krupa et al. 2018) i.e. the development of intermittent renewable energy sources (IRES). According to government plans, the aspect related to infrastructure will be a key element in the development of the electromobility market in 2019-2020. The number of charging stations is increasing. The electromobility meter (PSPA 2020a) have been shown, that there are 1173 charging stations (on July 7, 2020). However, this is not enough to dispel the doubts of future owners of electric vehicles regarding safe, reliable journeys around the country, with a guaranteed possibility of recharging the car and reaching the destination in a short time. However, despite these restrictions, the number of electric cars on Polish roads is growing. According to the data of the European Automobile Manufacturers Association (ACEA 2020) on the sale of electric cars in Europe in 2019, in our country 1,490 electric cars were added in 2019 compared to 620 units recorded a year earlier. Although even after deducting the fleet of Innogy Go (electric car sharing service in Warsaw), the year-on-year increase in the number of cars was almost $60 \%$ (with Innogy Go: $+140 \%$ ), compared to the progress that is taking place in other European countries, these are not statistics placing Poland at the forefront of countries in terms of the development of electric vehicle networks.

According to sales data, the number of internal combustion cars or diesel cars significantly exceeds the number of electric cars sold. These data are presented in Table 2.

Electric cars accounted for $0.2 \%$ of all cars sold, more or less the same number was plug-in hybrids, while classic hybrids took up almost $7 \%$ of the market. In Q1 2020, the number of registrations of all-electric cars and plug-in hybrids amounted to $1,705-86 \%$ more than in the corresponding period of 2019 - this is the result of data collected by the Polish Alternative Fuels Association (PSPA) and the Polish Association of Automotive Industry (PZPM) presented on the PSPA website under the slogan Electric Mobility Meter. As the number of vehicles increases, the generally accessible charging infrastructure is also developing. At the end of Q1 2020 (PSPA 2020a), there were 1,114 electric vehicle charging stations (2,067 points) in Poland, 31\% of which were fast direct current (DC) charging stations and $69 \%$ slow alternating current (AC) chargers with a capacity of less than or equal to $22 \mathrm{~kW}$. In Poland, the fastest charging station currently has a power of $150 \mathrm{~kW}$. However, there are only a few such points in the country. 
TABLe 2. New car sales statistics in Poland for 2019

TABELA 2. Statystyki sprzedaży nowych samochodów w Polsce w 2019 roku

\begin{tabular}{|l|c|c|}
\hline \multicolumn{1}{|c|}{ Propulsion system of vehicle } & Number of cars sold in 2019 & Number of cars sold in 2018 \\
\hline Gasoline cars & 394,519 & 368,011 \\
\hline Cars with diesel engines & 111,082 & 131,023 \\
\hline Hybrid electric vehicle, HEV & 38,716 & 23,902 \\
\hline Cars with alternative fuels & 8,143 & 7,545 \\
\hline Plug-in hybrid electric vehicle, PHEV & 1,200 & 759 \\
\hline
\end{tabular}

Source: European Automobile Manufacturers’ Association (ACEA 2020).

\section{The role of technical parameters - distance and charging costs}

The cost of charging an electric car depends on several factors. If the vehicle is charged only at home, from an electric socket, the price depends mainly on the tariff and the supplier, in recent years it was about EUR 0.14/kWh (CSO 2019; Kryzia et al. 2020a). An alternative to home charging is to use available city chargers. Some of such points are available for free, while the amounts of fee for paid charging are presented in Table 3 - according to the price list of the largest operator of a network of chargers in Poland in terms of the number of charging points company Greenway (Greenway Poland 2020).

TABLE 3. Electric vehicle charging prices at Greenway stations

TABELA 3. Ceny ładowania samochodów elektrycznych na stacjach Greenway

\begin{tabular}{|c|c|c|c|c|c|c|c|}
\hline \multicolumn{2}{|c|}{ Type of service: } & \multicolumn{2}{c|}{ STANDARD } & \multicolumn{2}{c|}{ PLUS } & \multicolumn{2}{c|}{ MAX } \\
\hline type & power [kW] & $\begin{array}{c}\text { price } \\
{[\text { EUR/kWh] }}\end{array}$ & $\begin{array}{c}\text { max. time } \\
{[\mathrm{min}]}\end{array}$ & $\begin{array}{c}\text { price } \\
{[\text { EUR/kWh] }}\end{array}$ & $\begin{array}{c}\text { max. time } \\
{[\mathrm{min}]}\end{array}$ & $\begin{array}{c}\text { price } \\
{[\text { EUR/kWh] }}\end{array}$ & $\begin{array}{c}\text { max. time } \\
{[\mathrm{min}]}\end{array}$ \\
\hline AC & LoD & 0.253 & 180 & 0.253 & 180 & 0.253 & 180 \\
\hline DC & $<40$ & 0.438 & 60 & 0.318 & 90 & 0.258 & 105 \\
\hline DC & $>40,<150$ & 0.487 & 45 & 0.353 & 60 & 0.287 & 90 \\
\hline DC & $>150$ & 0.576 & 30 & 0.420 & 45 & 0.331 & 60 \\
\hline
\end{tabular}

Source: Charging services price list Greenway, Poland 2020 (Greenway 2020). 
The comparison of the cost of driving $100 \mathrm{~km}$ by an electric car and, for example, a compact class car equipped with a diesel engine is as follows. A diesel car consumes an average of about $7 \mathrm{dm}^{3}$ of fuel per 100 kilometers, which costs EUR 7.2. The same distance behind the wheel of an electric car with an energy consumption of $19 \mathrm{kWh} / 100 \mathrm{~km}$, with electricity costs of EUR $0.14 / \mathrm{kWh}$, gives a bill of EUR 2.7. However, assuming that the vehicle will be charged only at free points, then the cost would even be zero. However, it should be taken into account that the cost that the owner of the electric vehicle must consider is the time that they waste on charging with free chargers. However, on the other hand, ever increasing electricity bills are not conducive to the pro-ecological attitude of replacing the car with an electric one. Initially, gas stations offered free car charging to attract customers. However, at present Lotos charges at its stations (except for the promotional offer, when charging is free), Orlen will do the same within six months. At Lotos stations, the driver will pay EUR 5.3 regardless of the charging length and the amount of energy consumed.

\section{Subsidies for vehicle purchase}

One of the key barriers to switching to an electric car is the price of an electric vehicle itself. One of the incentives for potential electrician owners is the system of government subsidies. Currently, the subsidies for an electric car are up to PLN 18,750, but not more than $15 \%$ of its price, with the maximum price of an electric vehicle amounting to PLN 125,000. This is the result of the "Green car - co-financing the purchase of an electric passenger car (M1)" coordinated by the National Fund for Environmental Protection and Water Management. The indicated price limit means that mainly buyers of city cars will benefit from the co-financing. There are currently eight models available on the Polish market with a fixed amount. The sum of funds planned to support the development of electromobility in Poland will amount to PLN 932.5 million. According to the data contained on the PSPA website (PSPA 2020a) the subsidy system will also cover such areas as the purchase of electric cars by entrepreneurs and local government units, collective public transport, charging infrastructure, electric school buses and the production of components. For comparison, in other European countries the subsidies are as follows: Germany - EUR 9,000, France - EUR 7,000, Serbia - EUR 5,000, Slovakia - EUR 8,000, Romania EUR 10,000 . 


\section{Economy of using an electric car}

The following assumptions were made in the analysis (Burchart-Korol et al. 2020; Matuszewska et al. 2020):

$\checkmark$ Euro exchange rate EUR $1=$ PLN 4.5,

$\checkmark$ Electricity consumption per $100 \mathrm{~km}: 19 \mathrm{kWh} / 100 \mathrm{~km}$,

$\checkmark$ Fuel consumption per $100 \mathrm{km:} 7 \mathrm{dm}^{3} / 100 \mathrm{~km}$,

$\checkmark$ Cost of battery replacement EUR 16,000. As the initial battery is already included in the purchase price of the electric car, the cost was calculated at $320,000 \mathrm{~km}$ (or $2 \times 160,000 \mathrm{~km}$ ) Ultimately, the costs were set at EUR $0.05 / \mathrm{km}$ (included in NPV analyses),

$\checkmark$ The cost of servicing and replacement parts of a combustion car was assumed at EUR $0.03 / \mathrm{km}$,

$\checkmark$ Other costs were calculated differently, i.e. the difference between the costs for an electric car and a combustion engine.

In addition, Net Present Value (NPV) was calculated, according to Formula No. 1, for the following assumptions:

$\checkmark$ lifetime of car, $n=20$ years,

$\checkmark$ discount rate $(r)$ from $0 \%$ and $6 \%$ (Kryzia et al. 2020b),

$\checkmark$ initial investment cost $I 0$ i.e. the difference between the purchase cost of an electric car and a combustion engine car. $I 0$ also includes the subsidy (subsidies) for electric cars.

$$
N P V=\left[\sum_{t=1}^{n} \frac{C F_{t}}{(1+r)^{t}}\right]-I 0
$$

where:

$C F_{t}-$ the cash flow in the year $t$ [EUR],

$t \quad-$ year of the analysis,

$n \quad-$ lifetime of using electric car [year],

I0 - initial investment cost i.e. the difference between the purchase cost of an electric car and a combustion engine car. $I 0$ also includes the surcharge (subsidies) for electric cars [EUR],

$r \quad-$ discount rate $[\%]$.

$$
C F_{t}=(F C \cdot F U C-E C \cdot E U C+S C F-S C E) \cdot T D / 100 \quad\left[\frac{\mathrm{EUR}}{\mathrm{year}}\right]
$$

where:

$C F_{t}-$ the cash flow in the year t [EUR],

$F C \quad-$ fuel cost $\left[\mathrm{EUR} / \mathrm{dm}^{3}\right]$, 
$F U C$ - fuel consumption $\left[\mathrm{dm}^{3} / 100 \mathrm{~km}\right]$,

$E C \quad-$ electricity cost $[\mathrm{EUR} / \mathrm{kWh}]$,

$E U C$ - electricity consumption $[\mathrm{kWh} / 100 \mathrm{~km}]$,

$T D$ - total distance $[\mathrm{km} / \mathrm{year}]$,

$S C F$ - service cost (fuel car) per km [EUR/km],

$S C E$ - service cost (electric car) per km (including battery replacement cost) [EUR/km].

The following ranges of values are included in the calculations:

$\checkmark$ For I0: from EUR 0 to 7,500,

$\checkmark$ For electricity price for loading electric cars: from EUR 0.1 to $0.8 / \mathrm{kWh}$,

\ Distance per year of electric car: 10,000-50,000 km,

$\checkmark$ Fuel price: EUR $1-1.5 / \mathrm{dm}^{3}$.

The results in the form of Cash Flow in each year are presented in the distance, along with the electricity price for loading cars Figure 1 : a) for fuel price $=$ EUR 1 ; b) for fuel price $=$ EUR $1.25 ;$ c) for fuel price $=$ EUR 1.5 .

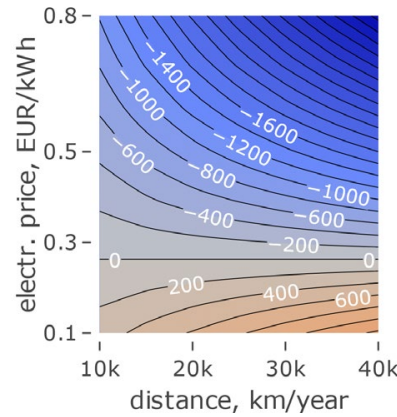

(a)

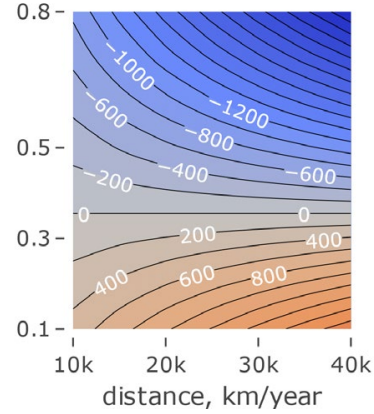

(b)

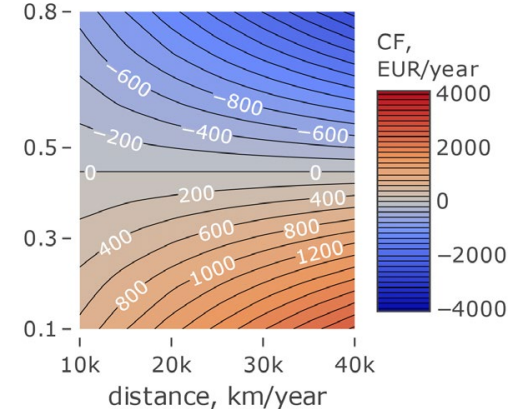

(c)

Fig. 1. The Yearly Cash Flow as a function of electricity price and yearly distance and for: (a) fuel price $=\mathrm{EUR} 1 / \mathrm{dm}^{3}$; (b) fuel price $=$ EUR $1.25 / \mathrm{dm}^{3}$; (c) fuel price $=$ EUR $1.5 / \mathrm{dm}^{3}$ Source: own study

Rys. 1. Roczne przepływy finansowe jako funkcja ceny energii elektrycznej i rocznego dystansu, dla: a) ceny paliwa $1 \mathrm{EUR} / \mathrm{dm}^{3} ;$ b) ceny paliwa $1,25 \mathrm{EUR} / \mathrm{dm}^{3}$; c) ceny paliwa $1 \mathrm{EUR} / \mathrm{dm}^{3}$

A Cash Flow of at least zero will be achieved for fuel price:

$\checkmark$ EUR $1 / \mathrm{dm}^{3}$; at the electricity price $<=$ EUR 0.27 , this means if electricity for car loading is bought lower than this price, Cash Flow is higher than 0;

$\checkmark$ EUR $1.25 / \mathrm{dm}^{3}$; at the electricity price $<=$ EUR 0.34 ;

$\downarrow$ EUR $1.5 / \mathrm{dm}^{3}$; at the electricity price $<=$ EUR 0.45 .

The results in the form of Net Present Value for price difference between an electric car and a petrol one (including surcharge/subsidies) $I 0=$ EUR 0, 2500, 5000, 7500 and 10,000 are presented in the distance, along with electricity price for loading cars Figure 2-6: a) for fuel price $=$ 
EUR 1; b) for fuel price $=$ EUR 1.25; c) for fuel price $=$ EUR 1.5. NPV values are obtained for discount rate $=0$.

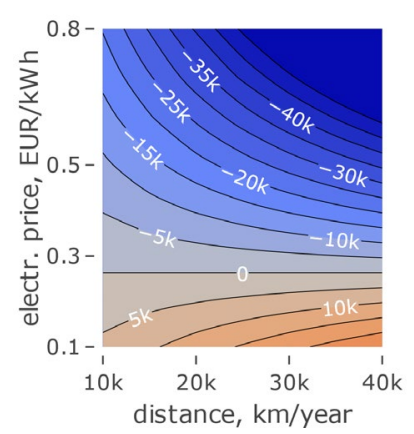

(a)

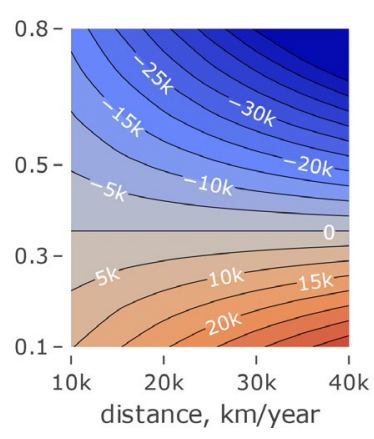

(b)

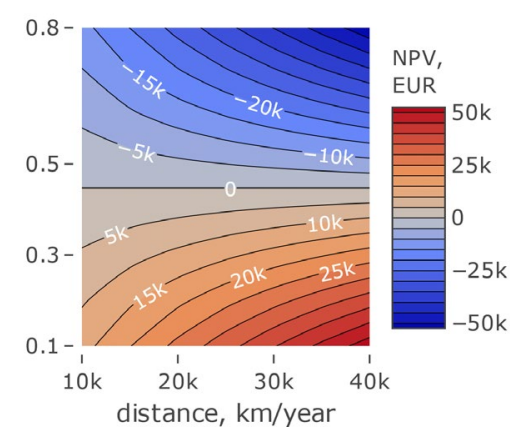

(c)

Fig. 2. The NPV as a function of electricity price and yearly distance and for: (a) fuel price $=$ EUR $1 / \mathrm{dm}^{3}$; (b) fuel price $=$ EUR $1.25 / \mathrm{dm}^{3}$; (c) fuel price $=$ EUR $1.5 / \mathrm{dm}^{3}$. I0 $=0$ EUR

Source: own study

Rys. 2. NPV jako funkcja ceny energii elektrycznej i rocznego dystansu, dla: a) ceny paliwa $1 \mathrm{EUR} / \mathrm{dm}^{3}$; b) ceny paliwa $1,25 \mathrm{EUR} / \mathrm{dm}^{3}$; c) ceny paliwa $1,5 \mathrm{EUR} / \mathrm{dm}^{3}$. I0 $=0$ EUR

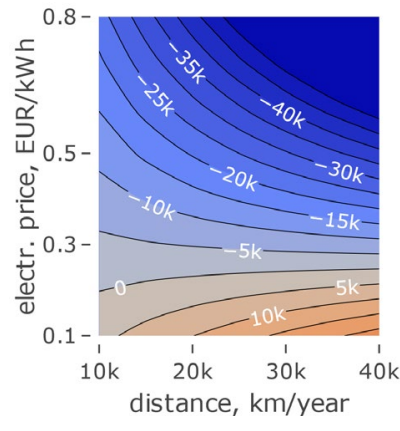

(a)

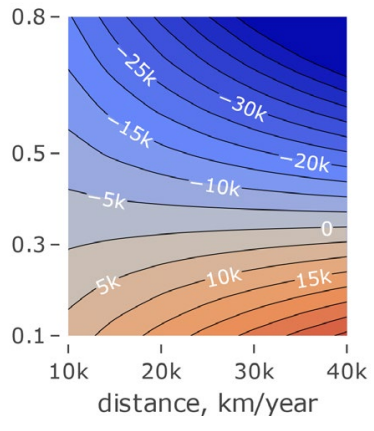

(b)

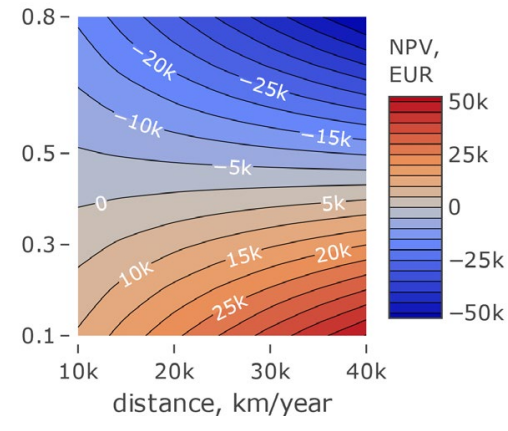

(c)

Fig. 3. The NPV as a function of electricity price and yearly distance and for: (a) fuel price $=$ EUR $1 / \mathrm{dm}^{3}$; (b) fuel price $=$ EUR $1.25 / \mathrm{dm}^{3} ;$ (c) fuel price $=$ EUR $1.5 / \mathrm{dm}^{3} \cdot I 0=$ EUR 2,500 Source: own study

Rys. 3. NPV jako funkcja ceny energii elektrycznej i rocznego dystansu, dla: a) ceny paliwa $1 \mathrm{EUR} / \mathrm{dm}^{3}$; b) ceny paliwa $1,25 \mathrm{EUR} / \mathrm{dm}^{3}$; c) ceny paliwa $1,5 \mathrm{EUR} / \mathrm{dm}^{3} \cdot I 0=2500 \mathrm{EUR}$

Moreover, NPV was calculated with a discount rate $r=0.06$ for the difference between the purchase price of an electric car and a combustion engine (including subsidies) for $I 0$ equal to EUR 5,000. The results are depicted on Figure 6. 


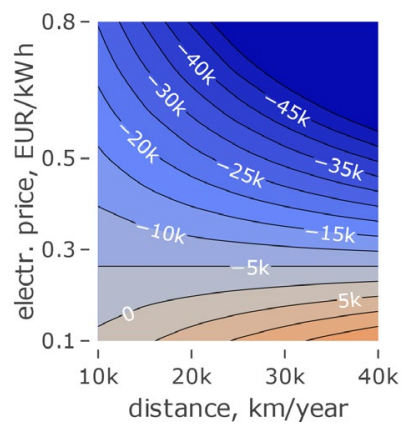

(a)

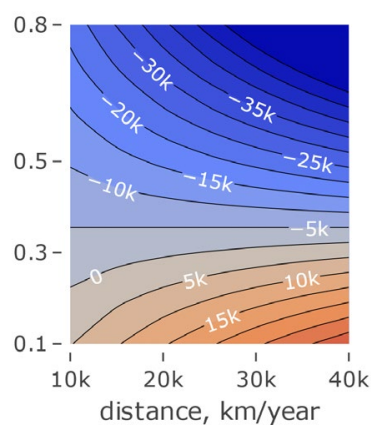

(b)

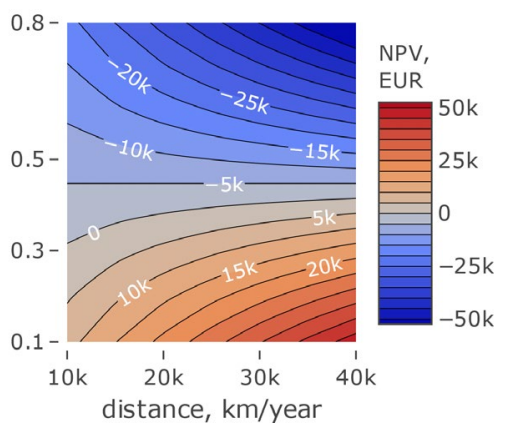

(c)

Fig. 4. The NPV as a function of electricity price and yearly distance and for: (a) fuel price $=$ EUR $1 / \mathrm{dm}^{3}$; (b) fuel price $=$ EUR $1.25 / \mathrm{dm}^{3}$; (c) fuel price $=$ EUR $1.5 / \mathrm{dm}^{3} . I 0=5,000$ EUR

Source: own study

Rys. 4. NPV jako funkcja ceny energii elektrycznej i rocznego dystansu, dla: a) ceny paliwa $1 \mathrm{EUR} / \mathrm{dm}^{3}$; b) ceny paliwa $1,25 \mathrm{EUR} / \mathrm{dm}^{3}$; c) ceny paliwa $1,5 \mathrm{EUR} / \mathrm{dm}^{3} . I 0=5000 \mathrm{EUR}$

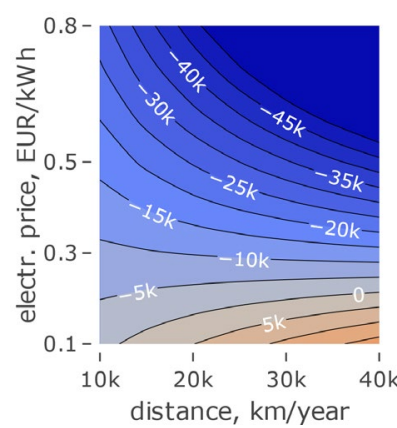

(a)

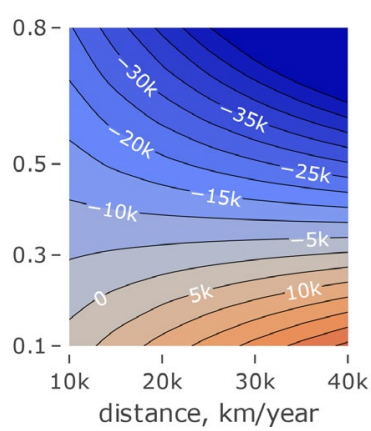

(b)

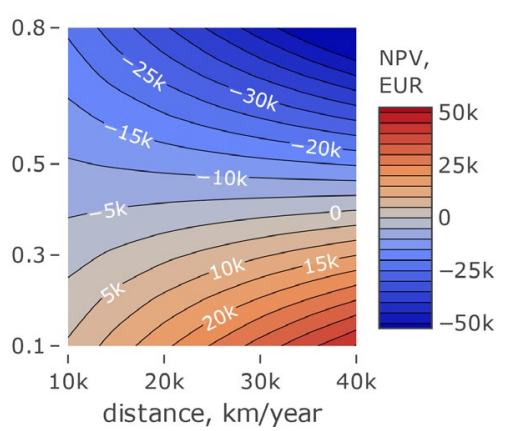

(c)

Fig. 5. The NPV as a function of electricity price and yearly distance and for: (a) fuel price $=$ EUR $1 / \mathrm{dm}^{3}$; (b) fuel price $=$ EUR $1.25 / \mathrm{dm}^{3}$; (c) fuel price $=$ EUR $1.5 / \mathrm{dm}^{3} . I 0=$ EUR 7,500 Source: own study

Rys. 5. NPV jako funkcja ceny energii elektrycznej i rocznego dystansu, dla: a) ceny paliwa $1 \mathrm{EUR} / \mathrm{dm}^{3}$; b) ceny paliwa $1,25 \mathrm{EUR} / \mathrm{dm}^{3}$; c) ceny paliwa $1,5 \mathrm{EUR} / \mathrm{dm}^{3} \cdot 10=7500 \mathrm{EUR}$

A NPV of at least zero will be achieved at fuel price $=$ EUR $1.25 / \mathrm{dm}^{3}$ for I0:

$\downarrow$ EUR 0 at the electricity price $<=$ EUR $0.34 / \mathrm{kWh}$ and there are no dependency on distance, with $r=0$;

$\checkmark$ EUR 2,500 at the electricity price $<=$ EUR $0.31 / \mathrm{kWh}$ and distance $>=20000 \mathrm{~km} / \mathrm{year}$, with $\mathrm{r}=0$; 


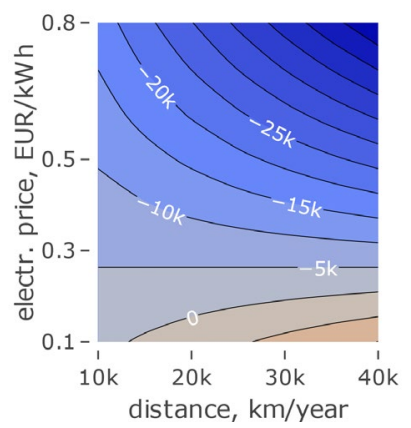

(a)

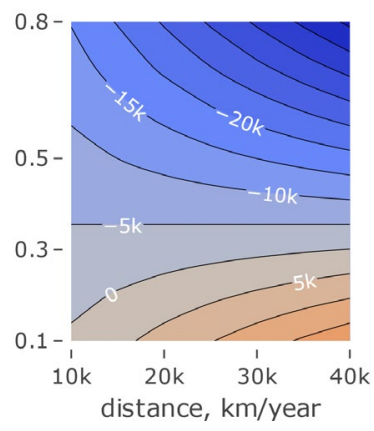

(b)

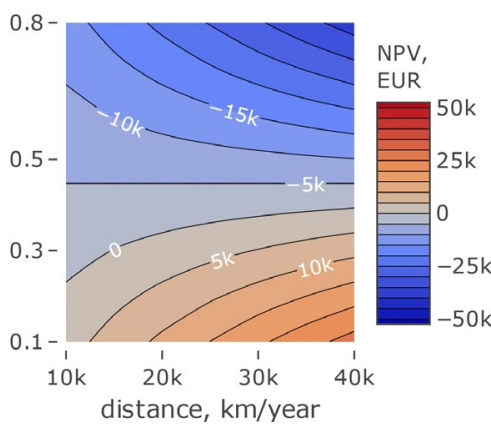

(c)

Fig. 6. The NPV as a function of electricity price and yearly distance and for: (a) fuel price $=$ EUR $1 / \mathrm{dm}^{3}$; (b) fuel price $=$ EUR $1.25 / \mathrm{dm}^{3} ;$ (c) fuel price $=$ EUR $1.5 / \mathrm{dm}^{3} . I 0=5000$ EUR; $\mathrm{r}=0.06$

Source: own study

Rys. 6. NPV jako funkcja ceny energii elektrycznej i rocznego dystansu, dla: a) ceny paliwa $1 \mathrm{EUR} / \mathrm{dm}^{3}$; b) ceny paliwa $1,25 \mathrm{EUR} / \mathrm{dm}^{3}$; c) ceny paliwa $1,5 \mathrm{EUR} / \mathrm{dm}^{3} . I 0=5000 \mathrm{EUR}, \mathrm{r}=0,06$

$\checkmark$ EUR 5,000 at the electricity price $<=$ EUR $0.28 / \mathrm{kWh}$ and distance $>=20,000 \mathrm{~km} / \mathrm{year}$, with $r=0$;

$\checkmark$ EUR 7,500 at the electricity price $<=$ EUR $0.25 / \mathrm{kWh}$ and distance $>=20000 \mathrm{~km} / \mathrm{year}$, with $\mathrm{r}=0$ and also:

$\checkmark$ EUR 5,000 at the electricity price $<=$ EUR $0.27 / \mathrm{kWh}$ and distance $>=20000 \mathrm{~km} / \mathrm{year}$, with $\mathrm{r}=0.06$.

\section{The impact of electric cars on the reduction of $\mathrm{CO}_{2}$ emissions}

Users of electric cars in Poland charge them mainly using electricity from the available mix in the electricity network, approx. $0.75 \mathrm{~kg} \mathrm{CO}_{2} / \mathrm{kWh}$. There is also an option to charge electric cars only from renewable energy or in different proportions (more favorable in terms of electricity) than in the energy mix.

The paper presents multi-variant calculations of the CER index expressing how much less $\mathrm{CO}_{2}$ emissions are caused by driving $1 \mathrm{~km}$ in an electric car in Poland in relation to a car with a combustion engine. 


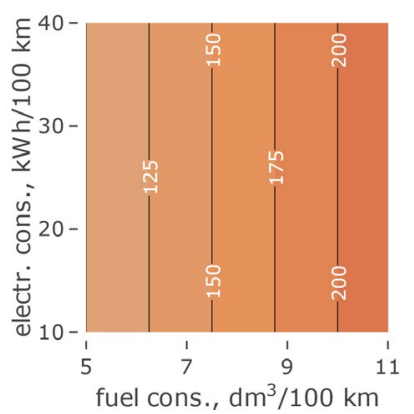

(a)

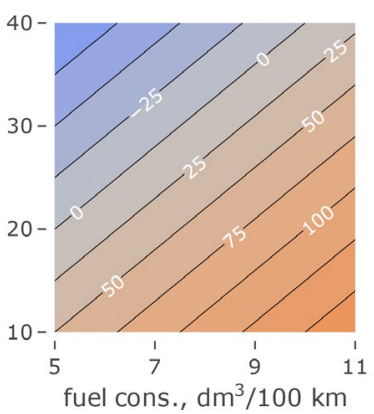

(b)

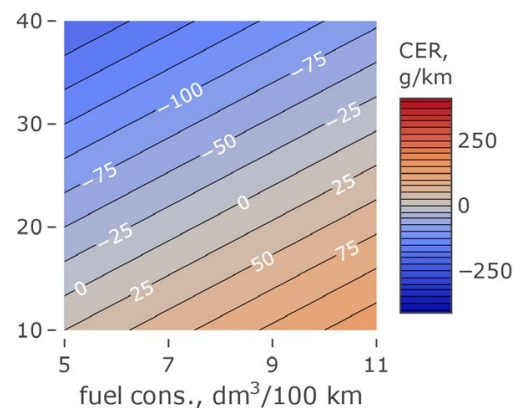

(c)

Fig. 7. The CER (carbon dioxide emission reduction) as a function of electricity consumption and fuel consumption and for: (a) carbon dioxide electricity emission factor: $0 \mathrm{~kg} \mathrm{CO} / 2 \mathrm{kWh}$ (only renewable energy); (b) carbon dioxide electricity emission factor: $0.5 \mathrm{~kg} \mathrm{CO}_{2} / \mathrm{kWh}$; (c) carbon dioxide electricity emission factor: $0.75 \mathrm{~kg} \mathrm{CO} / 2 \mathrm{kh}$. Emission factor $\mathrm{CO}_{2} / \mathrm{dm}^{3}$ - combustion and production of fuel

Source: own study

Rys. 7. Redukcja emisji $\mathrm{CO}_{2}$ jako funkcja zużycia energii elektrycznej i zużycia paliwa, dla: a) wskaźnika emisji $\mathrm{CO}_{2}$ z 1 kWh: 0 kg CO $2 /\left(\mathrm{kWh}\right.$; b) wskaźnika emisji $\mathrm{CO}_{2}$ z $1 \mathrm{kWh}$ : 0,5 $\mathrm{kg} \mathrm{CO}_{2} / \mathrm{kWh}$; c) wskaźnika emisji $\mathrm{CO}_{2}$ z $1 \mathrm{kWh}$ : $0,75 \mathrm{~kg} \mathrm{CO}_{2} / \mathrm{kWh}$. Wskaźnik emisji $\mathrm{CO}_{2} / \mathrm{dm}^{3}$ - spalanie i produkcja paliwa $=2 \mathrm{~kg} \mathrm{CO}_{2} / \mathrm{dm}^{3}$

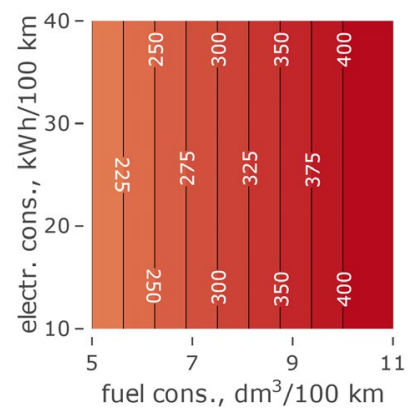

(a)

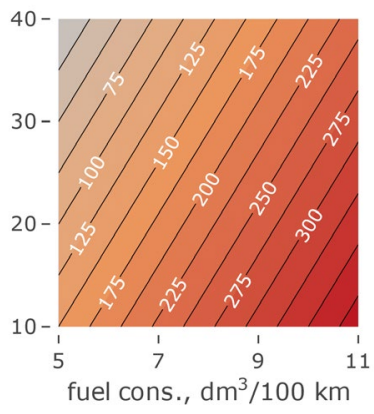

(b)

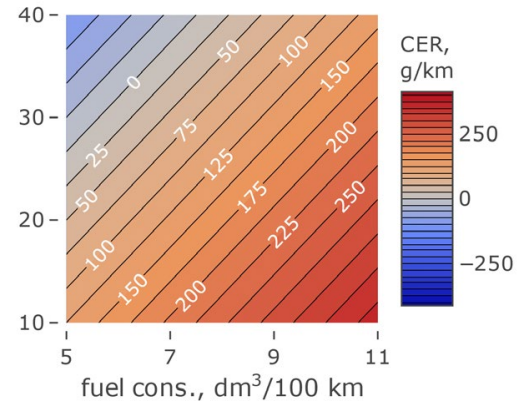

(c)

Fig. 8. The CER (carbon dioxide emission reduction) as a function of electricity consumption and fuel consumption and for: (a) carbon dioxide electricity emission factor: $0 \mathrm{~kg} \mathrm{CO} / \mathrm{kWh}$ (only renewable energy); (b) carbon dioxide electricity emission factor: $0.5 \mathrm{~kg} \mathrm{CO}_{2} / \mathrm{kWh}$; (c) carbon dioxide electricity emission factor: $0.75 \mathrm{~kg} \mathrm{CO} / / \mathrm{kWh}$. Emission factor $\mathrm{CO}_{2} / \mathrm{dm}^{3}$ - combustion and production of fuel

Source: own study

Rys. 8. Redukcja emisji $\mathrm{CO}_{2}$ jako funkcja zużycia energii elektrycznej i zużycia paliwa, dla: a) wskaźnika emisji $\mathrm{CO}_{2}$ z 1 kWh: 0 kg CO $2 /\left(\mathrm{kWh}\right.$; b) wskaźnika emisji $\mathrm{CO}_{2}$ z $1 \mathrm{kWh}$ : 0,5 $\mathrm{kg} \mathrm{CO}_{2} / \mathrm{kWh}$; c) wskaźnika emisji $\mathrm{CO}_{2}$ z $1 \mathrm{kWh}$ : $0,75 \mathrm{~kg} \mathrm{CO}_{2} / \mathrm{kWh}$. Wskaźnik emisji CO$/ \mathrm{dm}^{3}$ - spalanie i produkcja paliwa $=4 \mathrm{~kg} \mathrm{CO}_{2} / \mathrm{dm}^{3}$ 
The following ranges are included in the calculations (shown in Figures 7-8):

$\checkmark$ electricity consumption per $100 \mathrm{~km}$ in range: $10-40 \mathrm{kWh} / 100 \mathrm{~km}$,

$\checkmark$ fuel consumption per $100 \mathrm{~km}$ in range: $5-11 \mathrm{dm}^{3} / 100 \mathrm{~km}$ (Orzechowska and Kryzia 2015),

४ Carbon dioxide emission factor of electricity: $0-0.75 \mathrm{~kg} \mathrm{CO}_{2} / \mathrm{kWh}$,

४ Carbon dioxide emission factor of fuel: $2-4 \mathrm{~kg} \mathrm{CO}_{2} / \mathrm{kg}$ fuel (Kryzia et al. 2015). Fuel-related emissions not only occur in the combustion process in an internal combustion engine, but also in the process of e.g. refining.

For the average combustion of combustion cars $\left(7 \mathrm{dm}^{3} / 100 \mathrm{~km}\right)$, the CER indicator at least greater than or equal to zero will be achieved for:

$\checkmark$ consumption $=<29 \mathrm{kWh} / 100 \mathrm{~km}$ with $0.5 \mathrm{~kg} \mathrm{CO} 2 / \mathrm{kWh}$ and $2 \mathrm{~kg} \mathrm{CO}_{2} / \mathrm{dm}^{3}$ fuel,

- consumption $=<19 \mathrm{kWh} / 100 \mathrm{~km}$ with $0.75 \mathrm{~kg} \mathrm{CO} / \mathrm{kWh}$ and $2 \mathrm{~kg} \mathrm{CO}_{2} / \mathrm{dm}^{3}$ fuel,

४ consumption $=<40 \mathrm{kWh} / 100 \mathrm{~km}$ with $0.5 \mathrm{~kg} \mathrm{CO} 2 / \mathrm{kWh}$ and $4 \mathrm{~kg} \mathrm{CO}_{2} / \mathrm{dm}^{3}$ fuel,

$\checkmark$ consumption $=<36 \mathrm{kWh} / 100 \mathrm{~km}$ with $0.75 \mathrm{~kg} \mathrm{CO}_{2} / \mathrm{kWh}$ and $4 \mathrm{~kg} \mathrm{CO}_{2} / \mathrm{dm}^{3}$ fuel.

\section{Conclusions}

It is known that the development of civilization affects the quality of the environment around us. Therefore, technologies increasingly focus on environmentally friendly solutions. One of the ecological solutions in the motor industry are electric cars, thanks to which we can improve air quality, reduce exhaust emissions to the atmosphere as well as reduce noise emissions.

The study presents the advantages and disadvantages of using electric cars and the possibility of financing the purchase of such vehicles. Based on the data available by the producers and available reports, the savings that a potential user can obtain were calculated. Environmental benefits have also been demonstrated. The analyses of CER (carbon dioxide emission reduction) for electric vehicles in relation to internal combustion vehicles show a reduction in $\mathrm{CO}_{2}$ emissions compared to using only internal combustion vehicles. For the average combustion of combustion cars $\left(7 \mathrm{dm}^{3} / 100 \mathrm{~km}\right)$, the CER indicator at least greater than or equal to zero will be achieved for electricity consumption $=<19 \mathrm{kWh} / 100 \mathrm{~km}$ with $\mathrm{CO}_{2}$ electricity factor $=0.75 \mathrm{~kg} \mathrm{CO}_{2} / \mathrm{kWh}$ and $\mathrm{CO}_{2}$ fuel factor $2 \mathrm{~kg} \mathrm{CO}_{2} / \mathrm{dm}^{3}$ fuel.

The influence of CER especially in cities is an important argument for societies for which air quality is important. Despite the fact that the landscape of Polish roads has not changed drastically since the announcement of the "Plan for electromobility" in 2017 and Poles still mainly choose internal combustion cars, there is growing public awareness of the impact of motorization on the quality of life. Poles saw the need for changes and care for the natural environment. Although we are far from a revolution, and the change is being made in small steps, the interest in clean electric cars that do not emit harmful substances into the atmosphere is gaining importance. 


\section{References}

ACEA 2020. The automobile Industry Pocket Guide 2019-2020. [Online] https://www.acea.be/uploads/ publications/ACEA_Pocket_Guide_2019-2020.pdf [Accessed: 2020-12-05].

Augenstein, K. 2009. E-mobility as a sustainable system innovation. Insights from a captured niche. Wuppertal: Wuppertal Institute.

BrdulaK et al. 2020 - BrdulaK, A., ChaBEREK, G. and JAGODZiŃSKI, J. 2020. Determination of electricity demand by personal light electric vehicles (PLEVs): An example of e-motor scooters in the context of large city management in Poland. Energies 13(1), DOI: 10.3390/en13010194.

Burchart-Korol et al. 2020 - Burchart-Korol, D., Grzywacz-Gazda, M. and Zaręiska, K. 2020. Research and Prospects for the Development of Alternative Fuels in the Transport Sector in Poland: A Review. Energies 13(11), DOI: 10.3390/en13112988.

CSO 2019. Energy consumption in households in 2018 (Zuzycie energii w gospodarstwach domowych w 2018 r.). Warszawa: GUS (in Polish).

Drożdż et al. 2020 - Drożdż, W., Szczerba, P. and Kruszyński, D. 2020. Issues related to the development of electromobility from the point of view of Polish utilities. Polityka Energetyczna - Energy Policy Journal 23(1), pp. 49-64, DOI: 10.33223/epj/119074.

European-Comission 2011. Transport White Paper - roadmap to a single European transport area - towards a competitive and resource efficient transport system. Brussels.

Gajewski et al. 2017 - Gajewski, J., Paprocki, W. and Pieriegud, J. 2017. Perspectives of e-mobility development: opportunities and risk (in Polish). European Financial Congres, p. 5.

Greenway 2020. Sevice prices. [Online] https://greenwaypolska.pl/elektryczni-kierowcy/ [Accessed: 2020$-07-20]$.

JuRASZ, J. AND CiAPALA, B. 2019. A solar- and wind-powered charging station for electric buses based on a backup batteries concept. ICT for Electric Vehicle Integration with the Smart Grid, pp. 317-335. DOI: $10.1049 /$ pbtr016e_ch12.

KruPA et al. 2018 - KruPA, K., NieradKo, Ł. and HARAZiŃSKI, A. 2018. Prospects for energy storage in the world and in Poland in the 2030 horizon. Polityka Energetyczna - Energy Policy Journal 21(2), pp. 19-34, DOI: $10.24425 / 122770$.

Kryzia et al. 2015 - Kryzia, D., Kopacz, M. and OrzechowsKa, M. 2015. Estimation of carbon dioxide emissions and diesel consumption in passenger cars (Szacowanie emisji ditlenku węgla i zużycia oleju napędowego w samochodach osobowych). Zeszyty Naukowe Instytutu Gospodarki Surowcami Mineralnymi i Energia PAN 90, pp. 79-92 (in Polish).

Kryzia et al. 2020a - Kryzia, D., Kuta, M., Matuszewska, D, and OlczaK, P. 2020. Analysis of the potential for gas micro-cogeneration development in Poland using the Monte Carlo method. Energies 13(12), DOI: 10.3390/en13123140.

Kryzia et al. 2020b - KryZia, D., Kopacz, M. and KryZia, K. 2020. The Valuation of the Operational Flexibility of the Energy Investment Project Based on a Gas-Fired Power Plant. Energies 13(7), DOI: 10.3390/en13071567.

Matuszewska et al. 2020 - Matuszewska, D., Kuta, M. and OlczaK, P. 2020. Techno-Economic Assessment of Mobilized Thermal Energy Storage System Using Geothermal Source in Polish Conditions. Energies 13(13), DOI: 10.3390/en13133404.

Orzechowska, M. and KrYZia, D. 2015. Estimation of the future demand for natural gas in road transport in Poland. $5^{\text {th }}$ International Youth Conference on Energy (IYCE). Pisa, pp. 1-5.

PSPA 2020a. Electromobility meter (Licznik elektromobilności). [Online] https://pspa.com.p1/ [Accessed: 2020-07-07] (in Polish). 
PSPA 2020b. Polish EV Outlook 2020. [Online] https://pspa.com.pl/tag/polish-ev-outlook/ [Accessed: 2020-08-10] (in Polish).

World Health Organization 2020. Ambient (outdoor) air pollution, WHO. [Online] https://www.who.int/ news-room/fact-sheets/detail/ambient-(outdoor)-air-quality-and-health [Accessed: 2020-11-20].

Krystian MajchrzaK, Piotr OlczaK, Dominika Matuszewska, Magdalena Wdowin

\title{
Ekonomiczna i środowiskowa ocena korzystania z samochodów elektrycznych w Polsce
}

\author{
Streszczenie
}

Elektromobilność i samochody elektryczne to hasła, które w społecznym dyskursie w Polsce szczególnie intensywnie zaczęły nabierać znaczenia od roku 2017. Wówczas, wraz z ogłoszeniem „Planu Rozwoju Rynku Elektromobilności w Polsce”, ogłoszone zostały rządowe deklaracje dotyczące miliona samochodów elektrycznych, które mają się pojawić na polskich drogach do 2025 r. Już dziś wiadomo, że taki wynik jest w Polsce nie do osiągnięcia. Jak wynika z raportu Polskiego Stowarzyszenia Paliw Alternatywnych - PSPA (Polish EV Outlook 2020), w przypadku wprowadzenia dopłat do zakupu samochodów lub subsydiów takich jak np. możliwość odliczenia przez kupujących takie pojazdy całości VAT, liczba aut elektrycznych w Polsce w 2025 roku mogłaby wynieść ponad 280 tys. sztuk. Bez takiego wsparcia państwa polski park samochodów elektrycznych będzie dwukrotnie mniejszy. Wysokie ceny samochodów elektrycznych to jedna z kluczowych barier ograniczająca Polaków w decyzji związanej z zakupem pojazdu. Celem niniejszego artykułu jest analiza obecnego podejścia otoczenia społecznego do tematu ekologicznych, elektrycznych samochodów. Na ile, ze względu na czysto finansowe korzyści oraz inne aspekty, zmiana samochodu $\mathrm{z}$ tradycyjnego (zasilanego benzyną lub posiadającego napęd diesla) na samochód elektryczny jest dla potencjalnego właściciela samochodu korzystna. Artykuł składa się z części przeglądowej - prezentującej aspekty związane ze społeczno-ekonomicznymi korzyściami związanymi z zakupem samochodu elektrycznego. Zawiera także konkretne wyliczenia dotyczące opłacalności użytkowania takiego samochodu w warunkach polskich.

SŁowA KLUCZOWE: ekologia, transport, NPV, samochód elektryczny, elektromobilność 
